\title{
SYRIZA's Metamorphosis as Seen by The Turkish Left: A Critique of Leftism without Economics and Class Analysis
}

\author{
By Ulas Basar Gezgin*
}

\begin{abstract}
'SYRIZA' was like a magical word for the Turkish left and those hopeful for a leftist government in Turkey in 2015. 'SYRIZA' was the secret formula for the success of the left, a model to be followed to take over the government. Just like SYRIZA, the Turkish left had to be united and form a front-like organization. Thus, SYRIZA's pro-capital, pro-IMF and pro-establishment tendencies and activities were not noticed earlier among some of the Turkish left factions and its sympathizers and were hard to be accepted. SYRIZA had brought hope for the Turkish left, but then left its legacy as a symbol of disillusionment. However, it may not be true that the Turkish left drew its lessons from SYRIZA's symbolic and de facto shift. It appears that romanticism and idealizations are part of the identity and modus operandi of (at least some factions of) the Turkish left although it is claimed to be otherwise. In this article, views of various Turkish leftist writers on SYRIZA are presented, analyzed and discussed.
\end{abstract}

Keywords: Greece, Left, Mass Media, SYRIZA, Turkey.

\section{Introduction}

In this paper, Turkish left's perspectives on SYRIZA especially on its heydays are presented and discussed. As a research methodology, texts on SYRIZA penned by Turkish leftist writers, movements and parties are surveyed to identify the main elements of the discussions. It is observed that almost all factions of Turkish left were euphoric with SYRIZA's victory, but that euphoria would be dismantled soon. But from the very beginning, why had Turkish left as a whole with notable, but rare exceptions failed to see SYRIZA's true nature and promoted false hopes among their followers? The paper concludes that that is because of the leftist analyses without reference to the reality of the classes, the underlying economy and SYRIZA's proposed economic policies before its first victory. In fact this is not endemic to Turkish left. The mainstream left, globally speaking, reduces its analyses to cultural studies with a focus on self-proclaimed political identities without considering the infrastructure. The lethal test of left is in fact its economic policies, not its political views. The paper accordingly concludes with a number of recommendations for Turkish left which may have implications for the 'global' left.

*Professor, Duy Tan University, Vietnam. 


\section{SYRIZA: Early Signs}

Almost all factions of the Turkish left were quite happy after SYRIZA's January 2015 election victory. The leftist newspapers, journals and websites were full of articles analyzing SYRIZA's success and discussing how the same tactics could be utilized in Turkey. However, there were exceptions to this festive atmosphere, especially those affiliated with the Greek communist party and the Greek leftists other than SYRIZA. Let's start with these exceptions.

A cautious essay published before SYRIZA's election victory in 2015 (Alpan 2015) was prescient to propose that SYRIZA will possibly win, and discussed the unrealistic, romanticist and idealizing atmosphere of some factions of the Turkish left. Doubting the revolutionary and leftist character of SYRIZA even before the election, Alpan (2015) successfully chronicles deradicalization of the critical discourses of SYRIZA. The examples he focuses on are SYRIZA's discourses on what to do with the Greek debt and whether Greece would continue to be a member of NATO. Alpan (2015) wishes that SYRIZA would win, as he thinks that that is the way to show the reactionary character of reformism to people. Of course this understanding refers to Marxist idea of 'the deepening of the conflict'.

Alpan's cautiousness, prescience and SYRIZA-skepticism can be dated back to 2012. In Alpan (2012), after presenting a brief history of the Greek left, he claims that SYRIZA's radical rhetoric in no way matches its program and practice. Alpan (2012) also reminds the people that SYRIZA is not a new movement and reminds the readers of the deteriorated left alliances and coalitions in previous decades. According to Alpan (2012), even in 2012 SYRIZA was signing deals to reduce workers' wages for austerity. He draws our attention to the fact that even in 2010, SYRIZA's policy of alliance did not preclude fascist parties against Greek Communist Party. Ahmet Insel, a self-proclaimed leftleaning liberal writer claims that 7 months in power was sufficient for SYRIZA to turn from a radical left party to a reformist one (Insel 2015a), while he was hopeful and expecting a domino effect just before the January 2015 elections (Insel 2015b). However, Alpan (2012)'s elaborate depiction of SYRIZA's 'notorious past' testifies that the warning signs were visible far earlier than widely known. In fact, SYRIZA's pre-victory policies offered clear evidence for its future metamorphosis. A shorter but equally reasonable essay warning the likely sympathizers of SYRIZA prior to January 2015 elections was offered by Onur Devrim Üçbaş. Üçbaş (2015) briefly compares SYRIZA and Podemos and claims that sooner or later they will feel the pressure of the crossroad of changing sides. As both movements get massified and popularized their revolutionary discourse cools down to the extent that the final version looks like any other reformist party.

In another essay penned after 2012 elections by Foti Benlisoy, one of the leading commentators on the Greek left movements, it was stated that SYRIZA is far from clear about a number of vital issues such as debt, nationalization and European Union (Benlisoy 2012). On the other hand, he also cricitized the Greek Communist Party for sectarian policies and inability to formulate a relevant political program. Metin Çulhaoğlu from HTKP, a splinter group of the Turkish 
Communist Party ${ }^{1}$ and Fatih Polat from Evrensel newspaper ${ }^{2}$ were more cautious right after the January 2015 elections. Çulhaoğlu didn't reject SYRIZA outright and talked about historical possibilities while Fatih Polat favors a critical but not a skeptical attitude towards SYRIZA (Çulhaoğlu and Polat 2015). Meanwhile, Kemal Okuyan, one of the leading communist politicians was quick to call SYRIZA as a fake leftist government right after the January 2015 elections (Okuyan 2015).

Benlisoy appears to be more hopeful just before January 2015 elections (Benlisoy 2015a) and thereafter (Benlisoy 2015b). He would be saying that at least a party that challenges neo-liberalism and austerity measures would be in power and that SYRIZA's victory could be a catalyzer for anti-neo-liberal social movements. Benlisoy who had criticized SYRIZA earlier believed in a domino effect in 2015. Nevertheless Benlisoy identifies the dramatical changes in SYRIZA's discourse in recent years. He notices the increasing number of people saying that SYRIZA becomes another PASOK, but he thinks that such a position (i.e. acting like PASOK) can't be kept for long. Benlisoy draws our attention to the fact that SYRIZA becomes more like a leadership-oriented party rather than an organization with strong grassroots ties.

According to Yeşiltepe (2015) who occupies the middle position, sometimes negotiation and bargaining may be necessary for ultimate success. Sometimes revolutionary movements need to unite forces. Yeşiltepe is in the opinion that a new leftist government can't do nationalization the day after. He thinks that Soviet Union collapsed because of this mentality. However, the essay includes a number of unanswered questions and conditional statements (what if sentences) that didn't ultimately work that way. In contrast to Alpan, Benlisoy and Savran, Yeşiltepe asks the readers to wait more to see whether SYRIZA is 'in treason' or in tactical retreat on July 2015. Obviously, this is quite late to decide.

In his column after the January 2015 elections, Ergin Yildızoğlu, a prominent Marxist economist and writer blamed the Greek left which did not support SYRIZA. Greece was lucky that SYRIZA won without their support and he asks "but what if their non-support would lead to the victory of a conservative party?" (Yıldızoğlu 2015) According to him, non-SYRIZA left's voter base was 5-6\% only; so their campaign was negligible. It looks like he implicates the Greek Communist Party. Obviously, Yıldızoğlu was another victim of short-sighted thinking about SYRIZA.

Why could some factions of the Turkish left had more reasonable predictions? That is because they have been either affiliated with or active followers of the Greek left other than SYRIZA such as the Greek Communist Party and/or ANTARSYA. For example, Bolşevik website translated and published an interview with an ANTARSYA member criticizing SYRIZA (Skoufoglou 2015).

\footnotetext{
${ }^{1}$ HTKP is the acronym for People's Turkish Communist Party.

${ }^{2}$ As of 2017, 3 leftist dailies ('Cumhuriyet', 'Evrensel' and 'Birgün', listed in order by their foundation dates) are published in Turkey in contrast to tens of mainstream and pro-government newspapers. One can also consider to add 'Özgürlükçü Demokrasi', the Kurdish daily in Turkish language to this list.
} 


\section{SYRIZA: PASOK 2.0}

Munzam (2016a) states that SYRIZA turned out to be PASOK 2.0 with its policies serving the bosses and draws the readers' attention to the fact that SYRIZA and its far right coalition partner have no difference in terms of what to do about the Greek crisis. Both are supporting an economic model based on investments and exports and of course, austerity measures. Why do the Greek and foreign bosses like SYRIZA? According to Munzam (2016a), that is because of the fact that SYRIZA resumed the pro-capital, anti-labor policies from where its predecessors could not dare. Greek workers have already lost some portions of their salaries since SYRIZA took power. SYRIZA also kept the minimum wage as it is which was significantly lowered by its predecessors. The proposal by the Greek Communist Party to return to past minimum wage level was rejected. Munzam (2016a) also points out that in addition to the unemployment rate, the proportion of the part-time workers over the labor force has increased during SYRIZA's term. Furthermore, purchasing power of Greek citizens has dramatically decreased. Retirement at grave policy is implemented by SYRIZA which means retirement age is postponed and pensions were cut. The number of workers with social security has decreased as well, as well as their salaries, as stated above.

Munzam (2016b) reports that various sections of the Greek society such as workers against privatization, students and pensioners are protesting against SYRIZA. The government response was not different compared to SYRIZA's predecessors. A remarkable point made by Munzam (2016b) is the fact that Greek people, although protesting, although in great rage against SYRIZA feel hopelesnees as SYRIZA had been promoted as the 'ultimate solution'.

\section{Defections from SYRIZA and Grexit}

Prominent former SYRIZA members are featured in the Turkish left publications. For instance, Özgürlük (Freedom) Magazine published the translation of an interview with one of the leading voices of the leftist opposition within SYRIZA (the Left Platform) Costas Lapavitsas that originally appeared on Jacobinmag (Lapavitsas 2017a, 2017b). This translated interview was also reprinted on one of the leading online news sites, Gazete Duvar (Lapavitsas 2017c). According to Lapavitsas, the solution for the 'Greek crisis' was exiting the European Monetary Union and reinstating the former national currency, the drachma. While the metamorphosis of SYRIZA according to Munzam (2016b) is due to the fundamentally wrong assumption that the solution would be found in reforming capitalism rather than replacing it, Lapavitsas identification of the main problem with SYRIZA is naturally more nuanced:

"The problem with Syriza, however, was not its methods, but its strategy. They did not understand what Europe was about, how implacable the lenders were. Above all, they did not understand that the only way to combat the enormous 
power of the European Central Bank over the availability of liquidity in the economy was to produce a national currency. There was no other option for a left government. I told Tsipras this in private conversation but he did not want to hear it, for that would have involved a real break with the institutions of the European Union. And a break was not what he wanted by training, disposition, and political outlook." (Lapavitsas 2017)

Lapavitsas thinks that 'the Greek crisis' is similar to the Latin American debt crises, however a closer comparison could be with the German crisis after the $1^{\text {st }}$ World War. On this occasion, he hints that the situation may bolster Nazi-like equivalents and rise of a new Hitler in Greece. Same warning is voiced by Benlisoy (2012) who points out the popular rise of the fascist movement ('Golden Dawn') in Greece.

Another interview with a former SYRIZA member was the one that appeared on daily Evrensel. In the interview with Panagiotis Lafazanis, the former minister of productive reconstruction, environment and energy and the leader of the Popular Unity, a group that emerged out of SYRIZA forming the Left Platform, SYRIZA was designated as a traitor for Greek people (Koşar 2016). Lafazanis agrees with Lapavitsas about the solution: Grexit and Drachma. According to Lafazanis, by the new deals with the troika, Greece is increasingly colonized (Koşar 2016). In addition to Grexit and Drachma plans, he proposes to cancel the Greek debts and nationalization of the banks. Being part of the European Union, Lafazanis continues, brings neo-liberal policies as default (Evrensel 2016).

However, Tsipras does not view Grexit as a viable solution. According to him, it is not a progressive plan and it would bring worse consequences for Greek people (Aldoğan 2016). Of course, Tsipras lost credibility long time ago; so Grexit is still the only option not tried. In the near future, it won't be surprising to see that an increasing number of Greek citizens would vote for Grexit and Drachma.

Although the troika was said to be blackmailing the Greek government with Grexit, it also appears to be the only 'trump' card or bargaining tool the government has. However, SYRIZA precluded this possibility since its election campaign. Birdal (2015) briefly discusses the implications of Grexit. It would not only turn out to be one of the new episodes of the dismantlement process of the European Union, but Greece would be closer with Russia, due to cultural and historical ties which would not be an outcome that European hegemons would be fond of. Thus it appears that the barganing character of Grexit reigns supreme over its blackmailing function. It may well be a future possibility that Russia and/or China would be involved in restructuring of the Greek debts. China is especially notable, as the Chinese government designated and bought Piraeus Port as the gateway to Europe on its giant project to revive the Silk Road (Kolasa-Sikiaridi 2017, Mathews 2017, Putten 2016). In that sense, Greece is not without alternatives (cf. Kampanis 2017). 


\section{SYRIZA, HDP and ÖDP ${ }^{3}$}

Dimostenis Yağcioğlu claimed that people in Turkey were excited about SYRIZA's victory, that is why they exeggerated the party, and expected that people would have a more reasonable understanding of SYRIZA soon (Dede 2015). That was truly the case in Turkey. There are 4 major political parties in Turkey in terms of voter base: AKP is the pro-Islamic party in power. CHP is a mass party comprising secular, centrist, left etc. elements. HDP is the Kurdish party, aiming to be inclusive of liberal and left groups as well as minorities, while MHP is the Turkish nationalist party. Strangely enough, some mainstream rightist writers also likened SYRIZA's success to that of AKP (Benlisoy 2015b), as both got popular due to economic crisis. In fact, MHP is the only major party that was not used for comparison, while CHP was also compared with SYRIZA on other occasions. As Benlisoy (2015b) elaborately puts it, various Turkish political actors approached SYRIZA's victory instrumentally, rather than aiming at truly understanding what was happening in Greece. They were in competition to pose as the "SYRIZA of Turkey".

Especially June $7^{\text {th }}$ election (2015) which led to a short-term victory for HDP and again the short-term defeat of the incumbent government (AKP) allowed more people to draw parallels between HDP and SYRIZA. Although the Kurdish movement formed the backbone of HDP, it offered a uniting umbrella for various factions of the Turkish left with candidates from various leftist groups. SYRIZA as well was a united movement. Other than this point, the comparison was completely unfounded. For one thing, SYRIZA was not a party that emerged out of a national (minority) question. Secondly, the vote percentage of SYRIZA was quite higher than that of HDP. Furthermore, SYRIZA had no public image that is associated with blind terrorism as has been the case with HDP. Finally, the motivation for the voters to vote for SYRIZA and HDP were completely different: SYRIZA won due to anti-European sentiment in Greece and the economic situation while HDP won due to the regular Kurdish voter base and sizeable add-ons from leftists and liberals that hoped and expected that HDP could distance itself from or even condemn the deadly violence in the ongoing Kurdish war.

SYRIZA's message supporting HDP bolstered this unlikely comparison. Consequently, HDP and its followers were the last to get off the train of SYRIZA clappers. ${ }^{4}$ Another reason for this belatedness was the fact that HDP did not have a clear economic model. Politics had prevailed over the economy. There was no consensus about which economic model would be pursued. In fact a leading SYRIZA politician considered HDP rather than Kemalist CHP to be closer to SYRIZA since "they support the rights of ethnic and religious minorities, they are sensitive to gender issues and they have a pluralist perspective of the society" (Kanellopoulos, 2015) which naturally does not intend to draw any parallels in

\footnotetext{
${ }^{3}$ ÖDP is the abbreviation for Freedom and Solidarity Party.

${ }^{4}$ Even on a date as late as October 2016, HDP was still sending his representatives to SYRIZA's 2nd Congress (Aldoğan, 2016). Demirtaş, the co-head of HDP had a speech in this congress, still claiming that SYRIZA was HDP's brother party (Aldoğan, 2016).
} 
their economic models. Contrary to the attitudes of the Turkish left factions supporting not only political socialism, but also economical socialism, for HDP, SYRIZA's economic policies did not matter much.

With a similar perspective, Polat notes that HDP was more democracy- and identity-oriented while SYRIZA was more labor- and economically-oriented (Çulhaoğlu and Polat 2015). Polat also mentions the parallelisms drawn between Haziran Hareketi (the June Movement), a movement formed by various organizations that joined Gezi Park protests, but states that not all of the constituents of the movement was in favor of SYRIZA, as the movement also included parties affiliated with Greek Communist Party. On the other hand, HDP was not alone in his support for SYRIZA. ÖDP, a tiny socialist party that was originally formed as an umbrella of various leftist movements was another party that considered SYRIZA as his brother. In fact they are as fellow members of the Party of the European Left. Oğuzhan Müftüoğlu, a leader of one of the largest leftist movements in Turkish history even stated: "We are SYRIZA" (Müftüoğlu 2015a). He is among those who subscribed to the domino effect which didn't come true. He claimed that the success of SYRIZA could be replicated in Turkey through Haziran Hareketi (Müftüoğlu 2015b) which was refuted by recent events.

\section{Anybody Still Supporting SYRIZA?}

Mustafa Yalçıner, one of the leaders of Turkish 68 was critical about the Turkish 'liberal left' which hailed the rise of SYRIZA as a model for Turkey (Yalçıner 2015). He attributed SYRIZA's success to its exploitation of the anticapitalist sentiments of the Greek masses. According to him, the fact that SYRIZA was not willing to exit EU or even Eurozone was indicative of its petite bourgeoisie character from the very beginning. Superficial observances such as 'governing without ties' and refusing to swear by religion were falsely considered as signs of progress. However, as stated above when we discussed SYRIZA with regard to HDP, the true class character of SYRIZA would emerge in its economic policies which were not radical at all according to Yalçıner. He is also critical of the leftists in SYRIZA. He was surprised to see that SYRIZA MPs opposing Tsipras' bills form a minority.

It is highly likely that those who sticked to SYRIZA despite of submissive politics kept their posts due to careerism. The cool seat of the government is so sweet. Why would anybody resign from a minister post if s/he is driven by personal ambitions? On the other hand, the Popular Unity could not enter the parliament with $2.86 \%$ of the votes on September 2015 election. SYRIZA's losses were minimal, which was also surprising (Aldoğan 2015a). Maybe it was too early to be hopeful for the rise of the Popular Unity which had a very short time to prepare for the elections. They may win in the next election. Let us also note that the turnout rate was quite low $(56.6 \%)$ which shows a decline compared to January 2015 election $(63.6 \%)$. These figures are thought to reflect the widespread feeling of hopelessness among the Greek citizens (Benlisoy 2015b, Çetinkaya 2015). The Greek Communist Party (KKE) would likely to 
rise due to the disillusionments of SYRIZA. The party now is able to gain ground by claiming that KKE is the only party truly against the troika (Aldoğan 2015a). Benlisoy (2015) reflects on the possibility of SYRIZA forming a coalition with KKE rather than the far right. He thinks this possibility was not fully explored and exploited by both sides.

The question Yalçıner asks in the title of his column is meaningful: "Anybody Still Supporting SYRIZA?" However, some other Evrensel columnists are not as cautious as Yalçıner: For example, Imrek compares SYRIZA with Kobanê, and with euphoria names both as 'revolutionary development' (Imrek 2015). He claims that by SYRIZA and Kobanê victories, "humanity had two gates to hope and victory, one in Europe, another in the Middle East" (Imrek 2015). However, let us also note that those who misinterpreted SYRIZA is not only some factions of the Turkish left, but also some groups of European and American left, as Petras explains (Petras 2015).

\section{Taner Timur and Sungur Savran: The Missing Links}

Taner Timur, one of the greateast historians of the Turkish left surprised to see SYRIZA's self-confidence after January 2015 victory about the Greek debt. He thinks that they just inherited a wreckage that is quite hard to manage (Timur 2015). Timur provides an account of SYRIZA and the Greek crisis from a Marxist class perspective which is rare among the works about SYRIZA in Turkey. He states that the Greek crisis is due to a handful of ruling families that reaped enormous profits from privatization and by other means. They are Greek families, which means the roots of the Greek crisis is in the Greek oligarchs before European Union. The money borrowed from the troika is at the hands of these oligarchs, not at the hands of Greek people. Thus the solution had to be sought in heavily taxing oligarchs in the short term and remove class-based society in the long term. Grexit and Drachma would be the very first steps for true solutions for a crisis due to the usurpation of the public resources by the Greek oligarchs. As James Petras explains, there has been no way to bail out Greece by paying the debts incurred by the kleptocracts without radical measures (Petras 2015). Even acceptance of this debt as Greek people's debt and negotiating the terms to pay back are wrong in principle. In that sense, SYRIZA's term aggravated the situation not only due to the new and worse submissions to the troika, but also due to the fact that the kleptocrats were allowed to keep and transfer their illegal assets abroad (Petras 2015).

Timur's discussion reminds us the strange fact that most of Turkish leftist columnists think that they are doing a Marxist analysis of SYRIZA and the Greek crisis, but in fact they are not. There is no class reference in their discussions. That matches Ihsan Çaralan's (the chief columnist of Evrensel Daily) warning: He said that after SYRIZA's victory, some will run socialist analyses without referring to the notion of class (Çaralan 2015). Without class analysis, it is easy to understand why some factions of the Turkish left failed to grasp the true character of SYRIZA from the very beginning. 
The author of these words (Gezgin) has been skeptical of SYRIZA for a long time. That was because of his readings of Sungur Savran's essays (e.g. Savran 2015) about the matter. ${ }^{5}$ Savran had warned the readers about the possibility that SYRIZA may easily and quickly move to the capitalist camp. This move is hinted, according to Savran, by SYRIZA's belief that economic problems of Greece can be and will be solved by keeping to be a part of the European Monetary Union. A more blatant sign of this likely move could be seen in the fact that SYRIZA had no program to build socialism (Aldoğan 2015b, Savran 2015). According to Savran, as we saw the emergence and rise of a fresh movement like SYRIZA, we may also see that of a new truly Marxist movement in the future. Thus, SYRIZA as Savran states, is not an absolute political agent to reckon on. Class struggle is dynamic; which means subjective as well as objective conditions will change. SYRIZA may disappear in the near future to pave the way for another movement in this extraordinary period of Greek history. Extreme times will lead to the formation of extreme leaders as well as extreme movements.

In Gezgin (2015) where SYRIZA's metamorphosis was called as 'Frankesteinization', the following were proposed for why SYRIZA could not be considered as a leftist movement:

- Without an economic model or without designation of an economically socialist model, whether a party is a socialist or not is a moot issue.

- On July, SYRIZA had removed leftist cabinet members.

- An aggressive and tragical continuity between how SYRIZA and its predecessors treat protestors was to be noted.

- SYRIZA's preference for a far right partner to form coalition rather than tiny leftist parties is questionable. A member of the coalition partner was appointed for National Defense Ministry which could be considered as a key post for nationalist politics.

- SYRIZA's minister of finance was not a Marxist, he was a Keynesian which aimed to reform capitalism by government intervention.

- By SYRIZA's support, Prokopis Pavlopoulos who was the Minister of the Interior when Alexis (Alexandros Grigoropoulos) was killed was appointed as the president of Greece (still in this position).

Thus, there were notable signs pointing out SYRIZA's fast and forward metamorphosis, but this was ignored by Turkish left factions. This ignorance is also fed by the fact that none of the major parties in Turkish politics is socialist or even defines itself as leftist. CHP, the second party in the parliament is the founding party which oscillates between nationalism, etatism, social democracy and political protectionism, while HDP, the third party is an umbrella organization led by the Kurdish movement and supported by tiny little leftist parties and factions. The way they interpret SYRIZA and situate themselves vis-à-vis SYRIZA is unsurprisingly affected by the characteristics of their organizational

${ }^{5}$ Of course, that doesn't mean that they (both Savran and Gezgin) would be fail-proof in future occasions. 
structure. That was another reason for Turkish left's euphoria over SYRIZA's victory. Economic policies of CHP is based on IMF-styled social democracy (which is obviously contradiction in terms) and those of HDP is based on liberalism without identifying the real sources of economic exploitation and oppression.

\section{Conclusion}

Some of the Turkish left factions were quite euphoric after SYRIZA's victory, as the result, they thought, confirmed the fact that leftist ideology was still the hope for humanity. They expected a Lenin, but Tsipras turned out to be a Kerensky in his attempt to save and restore the status quo. They even expected a butterfly effect ultimately sweeping Turkey on the way (e.g. Ünker 2015). In fact, this was not only Turkish leftists' wishful thinking, it was also the nightmare of the financiers (Ünker 2015). A likely Grexit was expected to drive the final nail in European Union's coffin. 2 years after what they wrote, it is somewhat surprising to see that some of the essays about SYRIZA were removed from Turkish left factions' websites. It looks like they ultimately understood that they were wrong. But will they draw relevant lessons for future look-alikes of SYRIZA in Turkey, in Greece or anywhere else applicable? That is the billion-drachma question.

The way to accommodate SYRIZA's metamorphosis can't be removing proSYRIZA articles penned by the Turkish leftists. They should stay as they are. A better way is self-criticism, acknowledgment of the fact that analyses can sometimes be wrong, and identication of the source of the problem which is leftism without economics and class analysis. Another way is to form close ties with the political organizations of the world to receive more accurate information and commentary. As discussed before, the Turkish leftist factions which were right about SYRIZA from the very beginning either had close ties with the Greek left or conducted class analysis referring to the economic policies of SYRIZA. Particularism as to SYRIZA would be another error to avoid. The source of the wrong analyses among some factions of the Turkish left is not peculiar to the matter of SYRIZA, it is endemic and universal.

To conclude, the Turkish left needs class analysis referring to economic relations rather than self-proclaimed political designations (e.g. 'Radical Left Party') and closer ties with the international left. Drawing lessons from the errors committed in analyzing SYRIZA will help the Turkish left to be less fallible in the future which may help to analyze the situations correctly which in turn can increase the likelihood of an emergence of a strong leftist movement with large masses of supporters in Turkey. 


\section{References}

Aldoğan S (2015a) SYRIZA Kazandı: Yunanistan'da Yola Troykayla Devam [SYRIZA Winner: Yola Troika in Greece Continued]. Evrensel. Retrieved from https://bit.ly/ 2KvP3GG. [Accessed 23 August 2017].

Aldoğan S (2015b) Yunanistan'da devrime 5 kala mı? [Is the revolution in Greece 5?] Evrensel. Retrieved from https://bit.ly/2z5j4ro. [Accessed 23 August 2017].

Aldoğan S (2016) SYRIZA Kongresinde Vaatler Var Somut Planlar Yok [Promises in SYRIZA Congress There are no concrete plans]. Evrensel. Retrieved from https://bit. ly/2u5bqrl [Accessed 23 August 2017].

Alpan AS (2015) SYRIZA, Yunanistan Anomalisi ve 'Ertesi Gün' [SYRIZA, Greece Anomaly and 'Next Day']. Sol. https://bit.ly/2u2U0vn. [Accessed 22 August 2017].

Alpan AS (2012) SYRIZA Nedir? [What is SYRIZA?] Sol.Retrieved from https://bit.ly/ 2KOinEu. [Accessed 22August 2017].

Benlisoy F (2015a) SYRIZA ve 'Sol Hükümet': İmkân ve Kısıtlar [SYRIZA and 'Left Government': Opportunities and Constraints]. Evrensel. Retrieved from https://bit.ly/ 2KNsuJq [Accessed 22 August 2017].

Benlisoy F (2015b) SYRIZA: Sonuçlar ve Olasıllklar [SYRIZA: Results and Probabilities]. Başlangıç Dergi. Retrieved from https://bit.ly/2NIRZ6i. [Accessed 23 August 2017].

Benlisoy F (2012) Yunan Seçimleri: Sosyalizmle Barbarlık Arasında [Greek Elections: Between Socialism and Barbarism]. Bianet. Retrieved from https://bit.ly/2MKyiUU. [Accessed 22 August 2017].

Birdal M (2015) SYRIZA'nın çıkmazı [SYRIZA's impasse]. Evrensel. Retrieved from https://bit.ly/2tTXfpS. [Accessed 23 August 2017].

Çaralan I (2015) Tahterevalli oyunu'nu çökerten umut! [Hope that crashed seesaw game!] Evrensel. Retrieved from https://bit.ly/2IR9Oqz. [Accessed 23 August 2017].

Çetinkaya D (2015) Yunanistan'da seçime düşük katılım halkın sandıktan umudunun olmadığının göstergesidir [Selective low participation in Greece is a sign that the public has no hope].Evrensel. Retrieved from https://bit.ly/2Np7YAL. [Accessed 23 August 2017].

Çulhaoğlu M, Polat F (2015) SYRIZA ve Sol: Seçim Zaferi Önemli, Takip Etmek Gerekir [SYRIZA and Left: Election Victory Is Important, Must Be Followed]. Birgün. Retrieved from https://bit.ly/2KKnm8V. [Accessed 22 August 2017].

Dede E (2015) Zaferden Sonra SYRIZA ve Balıklar [After Victory SYRIZA and Fish]. Agos. Retrieved from https://bit.ly/2IRMd97. [Accessed 22 August 2017].

Evrensel (2016) Lafazanis: Türkiye'deki demokrasi güçleri ile dayanışacağız [Lafazanis: We'll solidarity with the democratic forces in Turkey]. Evrensel. Retrieved from https://bit.ly/2z7B8Bp. [Accessed 23 August 2017].

Gezgin UB (2015) İki Solun Hikayesi: Uruguay'in Ak Partisi ve Syriza [Two Solunum Stories: Uruguay's AK Party and Syriza]. Bianet. Retrieved from https://bit.ly/2IQz 943. [Accessed 22 August 2017].

Imrek E (2015) Kobanê Zaferi ve SYRIZA'nın Başarısı [Kobanê Zaferi and SYRIZA's success]. Evrensel. Retrieved from https://bit.ly/2MNvrKK. [Accessed 23 August 2017].

Insel A (2015a) SYRIZA Radikal Sol Gömleği Çıkarırken [SYRIZA Radical Left Shirt Removal]. Cumhuriyet. Retrieved from https://bit.ly/2z9CV8U. [Accessed 22 August 2017].

Insel A (2015b) SYRIZA ve Yunanistan'in Avrupa anı [SYRIZA and the European moment of Greece]. Radikal. Retrieved from. https://bit.ly/2NqMfZk [Accessed 22 August 2017]. 
Kanellopoulos C (2015) Syriza Avrupa'nın Üstünde Dolaşan Hayalet mi? [Is Syriza the Ghost Wandering Over Europe?]. Yeni Arayls. Retrieved from https://bit.ly/2MK JyAE. [Accessed 22 August 2017].

Kampanis Z (2017) One Belt One Road: the turning point for the recovery of Greek economy? China Daily. Retrieved from https://bit.ly/2z9EeVm. [Accessed 23 August 2017].

Kolasa-Sikiaridi K (2017) Venture Promoting Piraeus Port as Hub for One Belt One Road. Greek Reporter. Retrieved from https://bit.ly/2Kymo3N. [Accessed 23 August 2017].

Koşar A (2016) Lafazanis: SYRIZA İhanet Etti, Sömürge Haline Getiriliyoruz [Lafazanis: SYRIZA Betrayed, We Are Being Colonized]. Evrensel. Retrieved from https://bit.l y/2MKLXva. [Accessed 23 August 2017].

Lapavitsas C (2017a) The Future of Greece. Jacobin Mag. Retrieved from. https://bit.ly/ 2KLKbfN. [Accessed 22 August 2017].

Lapavitsas C (2017b) Yunanistan'ın Geleceği [Greece's Future]. Özgürlük. Retrieved from https://bit.ly/2KID4Vf. [Accessed 22 August 2017].

Lapavitsas C (2017c) Syriza'da Duraklama Dönemi [The Period of Pause in Syriza]. Gazete Duvar. Retrieved from https://bit.ly/2IPpYR7. [Accessed 22 August 2017].

Mathews JA (2017) China's Takeover of the Port of Piraeus in Greece: Blowback for Europe. Global Research. Retrieved from. https://bit.ly/2KPW1SL. [Accessed 23 August 2017].

Müftüoğlu O (2015a) Biz SYRIZA’yız [We are SYRIZA]. Birgün. Retrieved from. https://bit.ly/2Kyg24n. [Accessed 23 August 2017].

Müftüoğlu O (2015b) SYRIZA Örneği Türkiye'de de Pekala Mümkün [Turkey also possible Well SYRIZA Example]. Birgün. Retrieved from https://bit.ly/2KLb0xg [Accessed 23 August 2017].

Munzam G (2016a) SYRIZA: Patronlarla Omuz Omuza [SYRIZA: Shoulders Shoulder with Bosses]. Sol. Retrieved from https://bit.ly/2u3JJLh. [Accessed 22 August 2017].

Munzam G (2016b) Syriza da Hep Kandırdı mı? SYRIZA Anonim Şirketi ve Hissedarları [Did Syriza always cheat? SYRIZA Anonim Şirketi and its shareholders]. Sol. https://bit.ly/2NqLIXl. [Accessed 22 August 2017].

Okuyan K (2015) Syriza'dan ibaret değil Yunanistan solu [Not just Syriza Greece left]. CNN Türk. Retrieved from https://bit.ly/2Nmfv38 [Accessed 22 August 2017].

Petras J (2015) Nasıl olur da 'katı sol', 'katı sağ'ın politikalarını kabul eder [How can we accept the policies of 'the strict left', the 'right']. Evrensel. Retrieved from. https://bit.ly/2IVSMYj. [Accessed 23 August 2017].

Putten FP, Montesano FS, V J, Ham P (2016) The Geopolitical Relevance of Piraeus and China's New Silk Road for Southeast Europe and Turkey. The Hague: Netherlands Institute of International Relations 'Clingendael'.Retrieved from https://bit.ly/2rm 16Yt. [Accessed 23 August 2017].

Savran S (2015) Syriza Tuzağ [Syriza Trap]. Sendika.org. Retrieved from https://bit.ly/ 2z8w4Na. [Accessed 22 August 2017].

Skoufoglou M (2015) SYRIZA'ya Karşı Sol Alternatif Yaratılmalı [Left Alternative Creation Against SYRIZA]. Bolsevik.org. Retrieved from https://bit.ly/2KwmrwW. [Accessed 22 August 2017].

Timur T (2015) Syriza Dersleri [Syriza Courses]. Sendika.org. Retrieved from https:// bit.ly/2MQuWQe. [Accessed 23 August 2017].

Üçbaş OD (2015) Syriza ve Podemos: Solun Yükselişi [Syriza and Podemos: Breathe Rise]. Marksist.org. Retrieved from https://bit.ly/2NsSnjM. [Accessed 22 August 2017].

Ünker P (2015) Syriza'nın zaferi kelebek etkisi yaratabilir [Syriza's victory can create butterfly effect]. Cumhuriyet. Retrieved from https://bit.ly/2tVrdts. [Accessed 22 
August 2017].

Yalçıner M (2015) SYRIZA'cı Kimse Kaldı mı? [Has anyone been a SYRIZA?] Evrensel. Retrieved from https://bit.ly/2lVLH11. [Accessed 23 August 2017].

Yeşiltepe M (2015) SYRIZA Aynasında Sol ve Temel Teorik Tezler [SYRIZA and Left and Basic Theoretical Theses]. Bianet. Retrieved from https://bit.ly/2NsBGVw. [Accessed 22 August 2017].

Yıldızoğlu E (2015) SYRIZA: Seçimlerden Önce ve Sonra [SYRIZA: Before and After Elections]. Cumhuriyet. Retrieved from https://bit.ly/2KL0Vnh. [Accessed 22 August 2017]. 
